\title{
STUDIES ON SELF AND CROSS COMPATIBILITY OF PIONEER AND CELEBRATION PLUM CULTIVARS GROWN AT EL-KHATATBA (MINUFIYA GOVERNORATE) EGYPT
}

\author{
Maklad, Mahmoud F. \\ Department of Horticulture, Faculty of Agriculture, Ain shams \\ University, Cairo, Egypt \\ E-mail:mfmaklad@gmail.com
}

\begin{abstract}
7 wo plum cultivars (Pioneer and Celebration), grown in a private commercial orchard at El-Khatatba region under the Egyptian climatic conditions, were used to examine their self and cross compatibility and or incompatibility between both of them during the two successive experimental seasons 2017/2018 and 2018/2019. The fluorescence microscope was used to determine the degree of self and cross compatibility and or incompatibility, initial, and final fruit set percentage were calculated. Pollens of the two plum cultivars exhibited high rate of viability after $24 \mathrm{~h}$ in T.T.C. test and the germinated pollens of Pioneer cv. on Celebration style tissue were the highest. The combination between Celebration $\times$ Pioneer seemed to be as high partial cross compatible compared to the other treatments. The two cultivars under this study considered as partial self-compatible. Pioneer cv. had a higher degree of partial selfincompatibility than Celebration cv. Therefore, they need pollinizer cultivars for a good fruit set. Concerning the percentage of fruit set, the data revealed that fruiting of Pioneer and Celebration plum cultivars were good in the initial and final fruit set percentage in both seasons. Open pollination gave a significant difference in the initial and final fruit set percentages between the two plum cultivars followed by cross and self - pollination.
\end{abstract}

Keywords: Plum cultivars, Pioneer, self-compatibility, pollen viability, fruit set

Plum, (Prunus salicina L.) is one of the important deciduous fruit trees cultivated in Egypt. The plum production is characterized by

The $1^{\text {st }}$ Scientific Conference of Plant Genetic Resources Department, Ecology and Dry Lands Agriculture Division, Desert Research Center "Plant Genetic Resources and Sustainable Development Under Egyptian Desert Conditions" 13-16 November, 2019, Sharm El-Sheikh, South Sinai, Egypt 
fluctuation from one year to another. This fluctuation depends on whether conditions, cultural practices, pest management and self and cross incompatibility between different cultivated varieties. The most common plum cultivars in Egypt are Santa Rosa, Japanese Beauty, Methley, Hollywood and Pioneer. Orchards planted with theses cultivars only have low production. Sharma and Mohapotra (2001) found that the final fruit set in self-pollinated tree are low compared to open or cross-pollinated trees. The studied plum cultivars have been classified according to the self-fertility into four groups: self-sterile, partially self-sterile, inter sterility and self and/ or cross incompatible. This problem has been extensively studied in plum (Suranyi, 1978; Arora and Singh, 1987 and Hartman and Stosser, 1994). All these researchers have found that cross-pollination is important for fruit set of the partial self-fertile and self/cross incompatible plum cultivars.

The total area planted with plum reached about 2,614 feddans with annual production of about 13,941 tons (Ministry of Agriculture Statistics, Egypt, 2015). Most of all plum cultivated area was concentrated in the Nile Valley and Delta districts. The reduction in the cultivated area and average productivity could be due to the unfavorable weather conditions during blossoming, which resulting decrease in the insect activity and pollination, especially for self-incompatible and self-sterile cultivars, which required pollinators for the success of fruit set and productivity. Most of cultivated plum in Egypt are self-incompatible and requires cross-pollination to improve fruit set. Pioneer plum cultivar is considered partially as a selfcompatible under the Egyptian conditions. Therefore, they also need pollinators (Abd Elaziz, 2005). Pioneer is an early, red-skinned plum variety. Skin is bright red and the flesh is a pale-yellow color. Pioneer was bred by Infuriate in South Africa released in 1995. Its harvest and availability are in late November from South Africa (Maklad and Ismaile, 2016). The important factor for successful plum growing is the knowledge of the cultivar's degree of self-fertility. Diploid plum species such as Prunus salicina L. and Prunus cerasifera E., are mostly self-incompatible. While fertility relations of the hexaploid European plum (Prunus domestica L.) varieties vary between self-fertility, partial self-fertility and selfincompatibility (Szabó, 2003). The main objective of this study is to examine the self and cross-compatibility and/or incompatibility between Pioneer and Celebration plum cultivars under the Egyptian environment.

\section{MATERIALS AND METHODS}

The research was conducted during the two successive seasons 2017/2018 and 2018/2019 to examine the self and cross-compatibility and or incompatibility between Pioneer and Celebration plum cultivars (Prunus salicina L.). The cultivars were nine years old budded on Okinawa 
rootstock. Planted at $4 \times 6 \mathrm{~m}$ under drip irrigation in a private farm located in El-Khatatba region (Minufiya Governorate, Egypt). The flowers from the two cultivars were collected at the balloon stage just one day before anthesis. To let the anthers, dehisce, the flowers were placed on paper in the laboratory at room temperature. After one day, the pollens of each cultivar were collected in glass tubes separately and considered as a pollinizer of such cultivar.

Pollen viability was determined using 2,3,5 triphenyl tetrazolium chloride (T.T.C.) staining solution (1 part 10\% T.T.C.: 10 -part $60 \%$ sucrose) according to the methods of Operle and Watson (1952). Seventy flowers were used, distributed over 2 or 3 trees. The hand pollination was carried out according to the method described by Wertheim (1996). Fixation of pistils was done daily for seven successive days after pollination. All samples were fixed in 70\% F.P.A. (5: 5: $90 \%$ by volume, formalin: propionic acid: $70 \%$ ethanol) immediately after the collection time. The fixed flowers were kept at $4^{\circ} \mathrm{C}$ in the refrigerator until staining then pistils were washed in running water for $24 \mathrm{~h}$ and softened for $2 \mathrm{~h}$ in $8 \mathrm{~N} \mathrm{NaOH}$. Then samples were washed overnight in running tap water. Finally, the flowers were stained with $0.1 \%$ aniline blue dissolved in $0.1 \mathrm{~N} \mathrm{~K}_{3} \mathrm{PO}_{4}$ solution and kept at $4^{\circ} \mathrm{C}$ until the microscopic examination according to the method of Kho and Baer, (1968), Preil (1970) and Abou El-Nasr (1987).

To follow the pollen germination and pollen tube growth, the styles and the stigmas were separated from the ovary, squashed gently under pressing coverslip. The slides were investigated under ultraviolet light of Leica fluorescence microscope. As described by Martin (1959).

To prepare pistils for examination under the fluorescent microscope, the style was separated from the ovary and the style was squashed. As mentioned in the pollination treatment, flowers of the mother cultivar at balloon stage were emasculated using hand forceps in all cross-pollination treatments. Immediately, cross-pollination was performed by applying the appropriate pollen to the receptive stigmas with a fine paintbrush about 400 flowers were pollinated, and then shoots were bagged in pergamin bag to prevent insect pollinations. Self-pollination treatment was performed by bagging 400 flowers per each cultivar at balloon stage. In addition, 400 flowers per each cultivar were left for open pollination. The numbers of the total flowers were counted at anthesis. Moreover, the fruits were counted after 15 to 21 days from pollination (initial fruit set).

Percentage of the initial fruit set was calculated as follows:

Initial fruit set percentage $=$ number of set fruits/total number of flowers $\mathrm{x}$ 100

Fruiting percentage was determined by counting the number of final remained fruits (before the date of harvest). Percentage of fruiting was calculated as follows:

Fruiting percentage $=$ number of final fruits/total number of flowers $\mathrm{x} 100$ 
Nyéki and Szabó (1996) established five groups of cultivars: entirely self-incompatible (fruit set $0 \%$ ), self-incompatible (fruit set from 0.1 to $1 \%$ ), partially self-fertile (fruit set 1,1 to $10 \%$ ), self-fertile (fruit set from 10.1 to $20 \%$ ) and highly self-fertile (fruit set above 20\%) according to Abd Elaziz et al. (2017).

The experimental design was randomized complete block with 5 replications. Data were statistically analyses according to the method of Duncan (1955).

\section{RESULTS AND DISCUSSION}

Table (1) illustrates the pollen viability of Pioneer and Celebration plum cultivars in the two seasons. Pollens of the two plum cultivars exhibited high rate of viability after $24 \mathrm{~h}$ in T.T.C., followed by the other period $(48 \mathrm{~h})$ during the two seasons. On the other side, there was no significant difference between cultivars in the first season. On the contrary, Pioneer cv. exhibited significantly higher viability of pollen grains (after 48 h), than Celebration cultivar in the second season. Generally, the differences among cultivars were slight with significant differences in the two seasons. Thus, it is evident from the present data that the two cultivars produced viable or fertile pollen grains. These results are similar to those obtained by Lee (1980) and Fayek et al. (2018), who found that pollen of Pioneer showed high rates of viability and germination as it reached $74.14 \%$ in comparison with the other cultivars 'Songold', 'Sapphire' and 'Santa Rosa'.

Table (1). Pollen grains viability in T.T.C. of Pioneer and Celebration plum cultivars in 2017/2018 and 2018/2019 seasons.

\begin{tabular}{lcccc}
\hline \multicolumn{2}{c}{ Percentage of the valiability of pollen grains in T.T.C. } \\
\hline & \multicolumn{2}{c}{$\begin{array}{c}\text { Season } \\
\mathbf{2 0 1 7} / \mathbf{2 0 1 8}\end{array}$} & \multicolumn{2}{c}{ Season } \\
& $\mathbf{2 4 1 8} \mathbf{~ h}$ & $\mathbf{4 8} \mathbf{~ h}$ & $\mathbf{2 4} \mathbf{~ h}$ & $\mathbf{4 8} \mathbf{~ h}$ \\
\hline Pioneer & $96.97 \mathrm{a}$ & $88.30 \mathrm{~b}$ & $90.00 \mathrm{ab}$ & $97.23 \mathrm{a}$ \\
\hline Celebration & $98.00 \mathrm{a}$ & $90.55 \mathrm{ab}$ & $99.18 \mathrm{a}$ & $88.00 \mathrm{~b}$ \\
\hline
\end{tabular}

\section{Self-compatibility}

The pollen tube growth in the pistil after self-pollination was determinant of self-compatibility in plum cultivars. The walls of the pollen tubes contain callouses (1,3-glucane), which binds with aniline blue during staining (Abd Elaziz et al., 2017). Microscopic examination revealed different degrees of Partial-incompatibility pollen tube growth. The pollen tubes of Pioneer cultivar showed levels of partially self-compatibility when pollinated with own pollens; some of the pollen tubes grew to the end of $1 / 3$ length of the style, 3 days after pollination (Fig. 1A). Nevertheless, in most 
cases, some of the styles showed abnormal pollen tube growth, which grew through the styles by spaced of callus plugs along to the tube and they reached the lower part of the style, 4 days after pollination (Fig. 1B). These results are similar to those obtained by Abd Elaziz et al. (2017), who found that Pioneer cultivar has a degree of partial self-incompatibility. On the same side, although most of the pollen grains of Celebration cultivar germinated on the stigma surface; the pollen tube grew slowly with heavy deposition of callose along to the tube where its growth stopped in the lower part of the style 4 days after pollination (Fig. 1C).
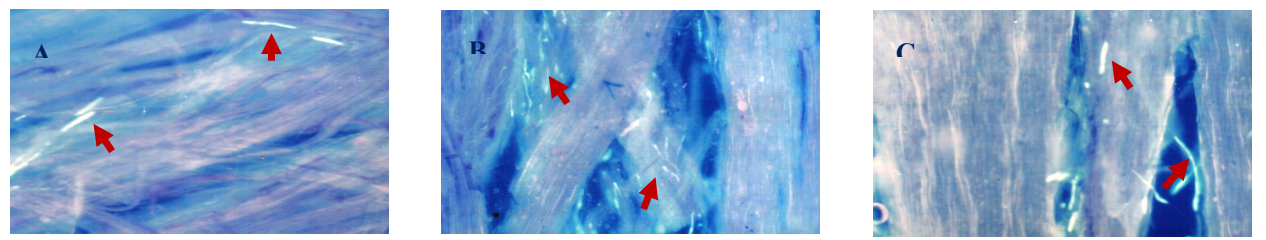

Fig. (1). Compatible charactrization: A. Pollen tubes grew to about $1 / 3$ length of the style. B. Abnormal pollen tube grew and reached to about $2 / 3$ length of the style. C. Pollen tube grew slowly to reach the base of the style with heavy deposition of callose.

Partial self-incompatibility was observed when Celebration cv. flowers were pollinated with Pioneer pollens. Some of the styles showed normal base on the obtained results (Fig. 2A). Also, Pioneer cultivar showed semi cross-incompatibility when pollinated with Celebration pollen grains. Moreover, the presence of short tubes from Celebration, which were unable to penetrate the stigma of Pioneer pistil as well as twisting tube as showed in Fig. (2B). However, most of the pollen tubes, which grew through the styles characterized by terminal callose plugs at the end of pollen tube (Fig. 2C). The two studied cultivars seemed to be partially self-incompatible cvs. However, Celebration cultivar has a degree of partial self-incompatibility higher than Pioneer cultivar.
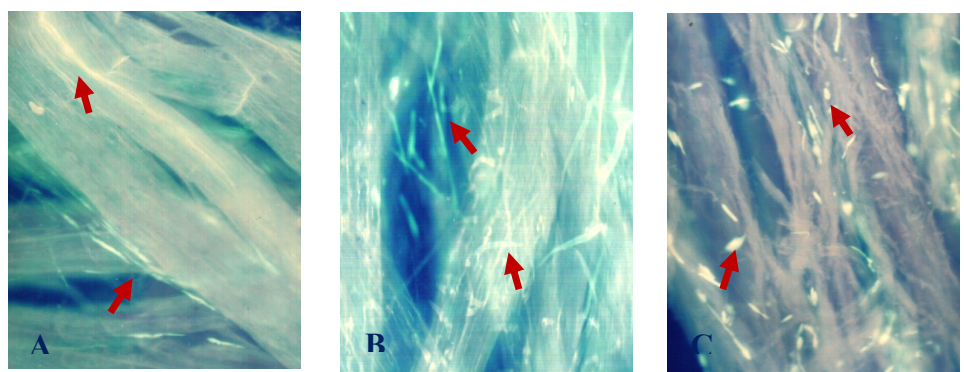

Fig. (2). Incompatible charactrization: A. Slowly grow in normal pollen tubes delays its arrival to the base of the style end. B. Short pollen tubes, which were unable to penetrate the style. C. Terminal callose plugs at the end of pollen tube, which stopped the growth. 


\section{Effect of the Different Pollination Treatments on the Percentages of Initial and Final Fruit Set}

Table (2) shows that, Pioneer open pollination as well as Pioneer as a female parent gave the highest initial fruit set percentage of 70.70, 69.51 and $61.87 \%$ in the first season, respectively. Celebration selfing gave high value of the initial fruit set percentage (80.49\%), followed by cross $(56.62 \%)$ and open $(53.06 \%)$ pollination, except in the first season. On the contrary, in the second season, the values of initial fruit set percentage after cross, self and open pollination was lower than the values in the first season, due to abscission of the flowers and premature fruits will be linked to ovular or embryo abortion and/or to abnormalities in the embryo sacs or the failure of fertilization (Burgos and Egea, 1993). In addition, Berezenko (1987) reported that, 3 periods of flower shedding and fruit drop were seen: the first to drop were flowers in which the pollen tubes had ceased growing at various stages along the style; then ovaries with fertilized embryo sac in which embryo development ceased at late stages. Also, various anomalies were detected in embryo and endosperm development in the young fruit shed. On the other hand, the combinations of Pioneer $\times$ Celebration exhibited the highest percentage of final fruit set percentage in the second season, followed by both Celebration selfing in the second season and Celebration open pollination. However, the final fruit set percentage after self pollination were generally less than open pollination, except in Celebration cv. in the first season, the mean of fruit set percentage of free pollinated flower was higher than artificial self pollinated flowers (Virtudes Andres and Duran, 1998). Open pollination gave significant differences in the initial and final fruit set percentages in the two cultivars under these studies in the most cases, followed by cross and self-pollination. Also, Keulemans (1990) reported that, low percentage fruit set was due to the presence of self pollen rather than insufficient pollen on the stigma. Low yield was due to insufficient cross pollination or pollination with unsuitable cultivars.

In conclusion, the two Pioneer and Celebration cultiares under this study considered as semi self incompatible. Morever, Pioneer and Celebration plum cultivars could be considered as promising due to their good partial cross compatible between them. Therefore, it is recommended to make widespread cultivation of these cultivars in Egypt.

Egyptian J. Desert Res., 69, Special Issue, 37-45 (2019) 
Table (2). Initial and final fruit set percentage after different pollination treatments of the two plum cultivares in 2017/2018 and 2018/2019 seasons.

\begin{tabular}{|c|c|c|c|c|c|c|c|}
\hline \multirow{2}{*}{$\begin{array}{l}\text { Pollinated } \\
\text { cultivar } \\
\text { (Female) }\end{array}$} & \multirow{2}{*}{$\begin{array}{l}\text { Pollinator } \\
\text { cultivar } \\
\text { (Male) }\end{array}$} & \multicolumn{3}{|c|}{$\begin{array}{l}\text { First Season } \\
(2017 / 2018)\end{array}$} & \multicolumn{3}{|c|}{$\begin{array}{c}\text { Second Season } \\
(2018 / 2019)\end{array}$} \\
\hline & & $\begin{array}{c}\text { Initial } \\
\text { fruit set } \\
(\%)\end{array}$ & $\begin{array}{c}\text { Final } \\
\text { fruit set } \\
(\%)\end{array}$ & Mean & $\begin{array}{c}\text { Initial } \\
\text { fruit set }(\%)\end{array}$ & $\begin{array}{c}\text { Final } \\
\text { fruit set } \\
(\%)\end{array}$ & Mean \\
\hline \multirow{3}{*}{ Pioneer } & Pioneer & $69.51 \mathrm{a}$ & $8.00 \mathrm{~b}$ & $38.75 \mathrm{AB}$ & $49.52 \mathrm{~b}$ & $10.10 \mathrm{c}$ & $29.81 \mathrm{~B}$ \\
\hline & Celebration & $61.87 \mathrm{a}$ & $9.77 \mathrm{~b}$ & $35.82 \mathrm{~B}$ & $70.67 \mathrm{a}$ & $9.29 \mathrm{c}$ & $39.98 \mathrm{~A}$ \\
\hline & $\begin{array}{c}\text { Open } \\
\text { (Control) }\end{array}$ & $70.70 \mathrm{a}$ & $10.58 \mathrm{~b}$ & $40.64 \mathrm{~A}$ & $53.14 \mathrm{~b}$ & $10.55 \mathrm{c}$ & $31.84 \mathrm{~B}$ \\
\hline \multicolumn{2}{|c|}{ Mean } & $67.36 \mathrm{~A}$ & $9.45 \mathrm{~B}$ & & $57.77 \mathrm{~A}$ & $9.98 \mathrm{~B}$ & \\
\hline \multirow{3}{*}{ Celebration } & Pioneer & $56.62 \mathrm{~b}$ & $6.41 \mathrm{c}$ & $31.51 \mathrm{~B}$ & $37.07 \mathrm{a}$ & $9.60 \mathrm{c}$ & $23.33 \mathrm{~A}$ \\
\hline & Celebration & $80.49 \mathrm{a}$ & $5.70 \mathrm{c}$ & $43.09 \mathrm{~A}$ & $36.15 \mathrm{a}$ & $5.33 \mathrm{c}$ & $20.74 \mathrm{AB}$ \\
\hline & $\begin{array}{c}\begin{array}{c}\text { Open } \\
\text { (Control) }\end{array} \\
\end{array}$ & $53.06 \mathrm{~b}$ & $6.52 \mathrm{c}$ & $29.79 \mathrm{~B}$ & $32.66 \mathrm{~b}$ & $4.72 \mathrm{c}$ & $18.69 \mathrm{~B}$ \\
\hline \multicolumn{2}{|c|}{ Mean } & $63.39 \mathrm{~A}$ & $6.21 \mathrm{~B}$ & & $35.29 \mathrm{~A}$ & $6.55 \mathrm{~B}$ & \\
\hline
\end{tabular}

Mean separation within columns or rows by Duncan's multiple range test, $5 \%$ level.

\section{REFERENCES}

Abd Elaziz, Y.S.G. (2005). Studies on sex compatibility and fruit set of some plum cultivars. M.Sc. Theses, Fac. Agric., Ain Shams Univ., Egypt.

Abd Elaziz, Y.S.G., Naglaa H. Shakweer and Gehan A.M. El-Hadidy (2017). Evaluation of Pioneer and Hollywood plum cultivars under sandy soil conditions in Egypt. Bull. Fac. Agric. Cairo Univ., 68: 411424.

Abou El-Nasr, N.M. (1987). The development of ovules by diploid and triploid apples varieties. Ph.D. Thesis, Fac. Agric., Hohenheim Univ.,West Germany.

Arora, R.L. and R. Singh (1987). Pollination requirement of sub-tropical plum (Prunus salicina Lindi.) Indian. J. Hort., 44 (3-4): 143-147.

Berezenko, N.B. (1987). Fruit drop in some varieties of cerasus avium L. Moench and prunus domestica L. Ukrains Kii-Botanichnii-Zhurnal., 44 (1): 46-49.

Burgos, L. and J. Egea (1993). Apricot embryo sac development in relation to fruit set. J. Hort. Sci., 68: 203-208.

Duncan, D.B. (1955). Multiple range and multiple test. Biometrics, 11: 1-24.

Fayek, M.A., T.A. Yehia, A.M. Hussien and A.M. Farag (2018). Self and cross-compatibility of 'sapphire' plum cultivar. Bioscience Research, 15 (4): 3117-3122. 
Hartman, W. and R. Stosser (1994). Biology of fertilization in some new varieties of plum and damson (Prunus domestica) Erwerbstbou., 36 (2): 37- 410.

Keulemans, J. (1990). Cropping behavior, flower bud formation, pollination and fruit set of different plum cultivars in Belgium. Acta. Hort., 283: 117-129.

Kho, Y.O. and J. Baer (1968). Observing pollen tubes by means of fluorescence. Euphytica, 17: 298-302.

Lee, C.L. (1980). Pollen germination, pollen tube growth and fertilization behavior in Prunus domestica L. pollen germination in vitro and in vivo. Gartenbuwñsenschaft., 45 (5): 228-235.

Maklad, M.F. and S.A. Ismaile (2016). Evaluation of Pioneer and Celebration plum cultivars under El- Khatatba region condition. J. Plant Prod., Mansoura Univ., 7 (7): 763-767.

Martin, F.W. (1959). Staining and observing pollen tubes in the style by means of fluorescence. Stain Tech., 34: 125-128.

Ministry of Agriculture and Land Reclamation Statistics (2015). Egypt.

Nyéki, J. and Z. Szabó (1996). Fruit set of plum cultivars under Hungarian ecological conditions. Acta Hort., 423: 185-192.

Operle, G.D. and R. Watson (1952). The use of 2,3,5-triphenyl tetrazolium chloride in viability tests of fruit pollens. American Socity for Horticultural Science, 61: 299 - 303.

Preil, W. (1970). Floureszenz-mikroskopische Beobachtungen des notengewebe. Zeiss. Inf., 18: 24-25.

Sharma, S.D. and R.K.D. Mohapotra (2001). Pollination studies in different species of plum. Himachal. J. Agri. Res., 25 (1/2): 58-65.

Suranyi, D. (1978). A new method for determining self-fertility in plum varieties. Acta Agronomica Academia Scientiarum Hungaricea, 27 (3/4): 247-257.

Szabó, Z. (2003). Plum (Prunus domestica L.). In: "Floral Biology, Pollination and Fertilisation in Temperate Zone Fruit Species and Grape”. Akadémiai Kiado, Budapest, p. 383-410.

Virtudes Andres, M. and J.M. Duran (1998). Self-incompatibility in spanish clones of Apricot (Prunus armeniaca L) tree. Euphytica, 101: 349355.

Wertheim, S.J. (1996). Methods for cross pollination and flowering assessment and their interpretation. Acta Hort., 423: 237-243.

Egyptian J. Desert Res., 69, Special Issue, 37-45 (2019) 


\section{دراسات على التوافق الذاتي والخلطي لأصناف البرقوق البيونيز

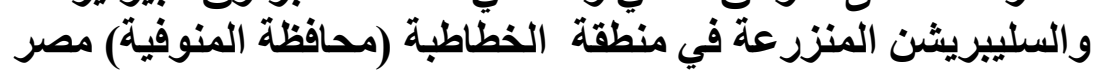

محمود فتحي مقلد

قسم البساتين، كلية الزر اعة، جامعة عين شمس، القاهرة

أجريت هذه الدراسة على صنفين من البرقوق (بيونير وسليبريشن) منزر عين في مزرعة

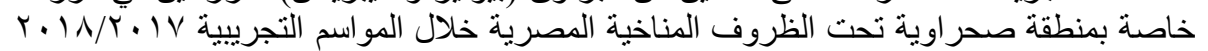

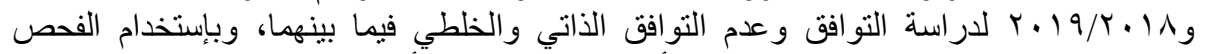

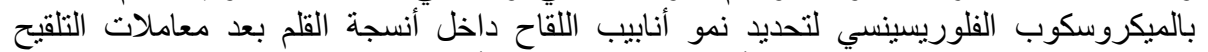

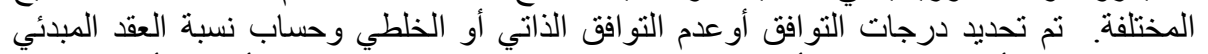

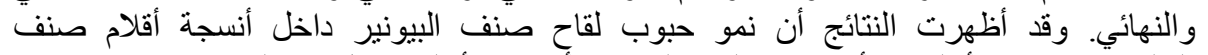

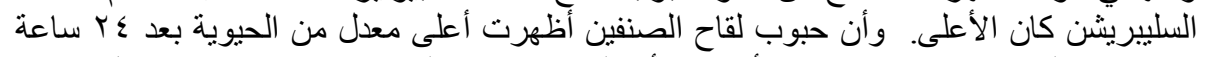

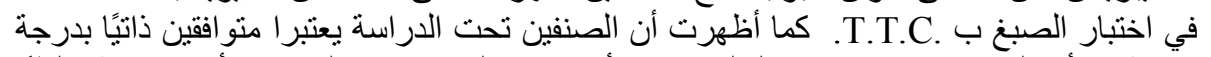

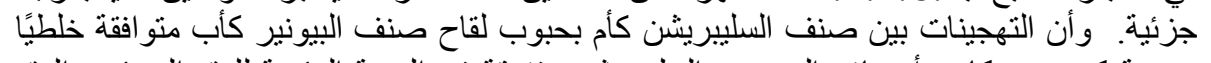

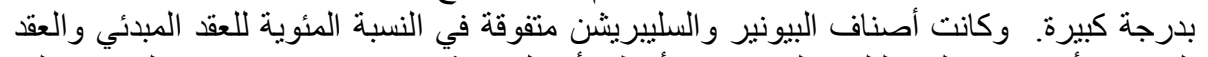

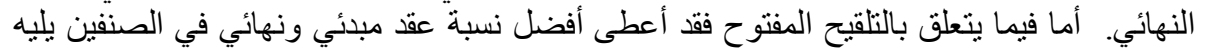
الخلطي في معظم الحالات ثم التلقيح الذاني.

Egyptian J. Desert Res., 69, Special Issue, 37-45 (2019) 